IOSR Journal of Pharmacy

e-ISSN: 2250-3013, p-ISSN: 2319-4219, www.iosrphr.org

Volume 2 Issue 6 || || Nov-Dec. 2012 || | PP.65-69

\title{
Evaluation of Pev and Hemoglobin Variations among Malaria Positive and Malaria Negative Patients, At the Ecwa Community Health Centre Bukuru, Jos. Nigeria.
}

\author{
${ }^{1}$ Meraiyebu Ajibola, ${ }^{2}$ Akintayo Christopher Oloruntoba, \\ ${ }^{1}$ Nenchi Dooshima Yetusoko \\ ${ }^{1 *}$ Department of Physiology, Bingham University, Karu Nasarawa State, Nigeria \\ ${ }^{2}$ Department of Physiology, University of Ibadan, Ibadan, Nigeria.
}

\begin{abstract}
Malaria is predominantly caused by plasmodium falciparum parasite. It is a major cause of mortality and morbidity in patients. It causes the excessive destruction of red blood cells during the parasites life cycle. Anemia is a predominant symptom of malaria patient. It is a hematological disorder caused by a decrease in the production of red blood cells, a bone marrow failure or by an increased destruction of red cells. This is because there is decreased erythropoiesis due to the malarial infection. There is the parasitization of red cells by the malaria parasite which leads to shortened survival or death of erythrocytes. Because of this destruction, packed cell volume and hemoglobin values are reduced when measured in malaria positive patients. This study was conducted among the malaria and non malaria of The ECWA Community Health Centre, Bukuru, Jos in Nigeria. Samples were obtained from malaria positive and malaria negative patients. Their packed cell volume and hemoglobin values were calculated. Result showed a significant difference in the packed cell volume values of the patients. Conclusively, there was a decrease in packed cell volume in malaria patients which seems to be due to the excessive destruction of red cells by malaria parasite.
\end{abstract}

Keywords-Hemoglobin, Maleria, PCV, Human subjects.

\section{INTRODUCTION}

Malaria is the number one cause of parasitic diseases. However, the causative agent is known to be Plasmodium transmitted by the bite of a female anopheles mosquito. Plasmodium was first isolated in blood of a patient in 1881 by Alpones Laveran (9). Four species of Plasmodium have been identified to cause malaria in humans: Plasmodium Falciparum, Plasmodium Vivax, Plasmodium Ovale, and Plasmodium Malariae. The two most common species are the P.Falciparum and the P.Vivax of which the most pathogenic is P.Falciparum (9). However, anemia is a very common presentation of malaria due to direct depression of erthropoiesis by malarial infection and the actual parasitization of red cells by the malarial parasite leads to shortened survival or death of erythrocytes (4).

Anemia is a condition in which the body does not have enough healthy red blood cells which are oxygen carrying cells produced mainly from the bone marrow under the influence of erythropoietin produced by the kidney. Anemia can be caused by kidney failure, blood loss, bonemarrow disease such as leukemia. Full blood count (FBC) is a test carried out to measure the size, number and shape of different types of cells (red blood cell, white blood cell, platelets) in the blood. It gives the amount of hemoglobin and packed cell volume (PCV) which is the volume of blood occupied by red blood cells. The term hematocrit is often used for this quality. Packed cell volume is expressed in percentage. PCV measurement can be done by centrifuging. PCV measurement is used in determining anemia and is used to calculate hemoglobin concentration (Hb)expressed in $\mathrm{g} / \mathrm{dl}$ and also to calculate Mean Corpuscular hemoglobin concentration (MCHC) which is the average hemoglobin concentration within the red blood cells. The pathophysiology of the anaemia of falciparum malaria is both complex and multifactorial, and results in a condition which is a major cause of mortality and morbidity in patients, especially children and pregnant women, living in malarial endemic areas. The importance of anaemia as a cause of death in malaria may well be underestimated because of difficulty in diagnosis, especially where parasitaemia may be low and the clinical picture may be confused with other causes of anaemia. Two clinical presentations predominate: severe acute malaria in which anaemia supervenes, and severe anaemia in patients in whom there have been repeated attacks of malaria. The major mechanisms are those of red cell destruction and decreased red cell production. Potential causes of haemolysis include loss of infected cells by rupture or phagocytosis, removal of uninfected cells due to antibody sensitization or other physicochemical membrane changes, and increased reticuloendothelial activity, particularly in organs such as the spleen. 
Decreased production results from marrow hypoplasia seen in acute infections, and dyserythropoiesis, a morphological appearance, which in functional terms results in ineffective erythropoiesis (12). A cross-sectional study was carried out from November 2007 to July 2008 in health units in Buea, Cameroon (14). Adult patients with fever or history of fever were included in the study. Information on socio-demographic variables and other variables was collected using a questionnaire. Malaria parasitaemia status was determined by microscopy using Giemsa stained thick blood smears. Haemoglobin levels were determined by the microhaematocrit technique. Another cohort studies conducted in areas of stable, perennial malaria transmission in Tanzania and Kenya, showed that malarial infection correlates with decline in haemoglobin concentration of less than $8 \mathrm{gl} / \mathrm{dl}$ (13). However, the aim of the study was to examine anemia using packed cell volume and hemoglobin concentration values in patients with malaria parasitaeamia and patients without malaria parasitaemia. Study patients include male and female (adults and children) in ECWA Community Health Program Primary Health Care Centre Bukuru, Jos. Nigeria.

\section{MATERIALS AND METHODS}

Study area: ECWA Community Health Program Primary Health Care Centre Bukuru, Jos Nigeria. The packed cell volume values used in the study were taken from 5th of March, 2011 to $13^{\text {th }}$ of October, 2011.

\subsection{Experimental Design}

In the study, 178 patients packed cell volume values were used. The target persons were grouped into group 1 to group 8 .

Group 1: Control group for adult male patients. They consisted of 24 patients and with their packed cell volume and $\mathrm{Hb}$ values.

Group 2: Malaria positive male adults which consisted of 32 patients and with their packed cell volume and $\mathrm{Hb}$ values.

Group 3: Control group for female adults. They consisted of 32 patients and with their packed cell volume and $\mathrm{Hb}$ values.

Group 4: Malaria positive female adult. They consisted of 32 patients and with their packed cell volume and $\mathrm{Hb}$ values.

Group 5: Control group for male children. This consisted of 17 patients and with their packed cell volume and $\mathrm{Hb}$ values.

Group 6: Malaria positive male children. This consisted of 15 patients and with their packed cell volume and $\mathrm{Hb}$ values. $\mathrm{Hb}$ values.

Group 7: Control female children. They consisted of 9 patients and with their packed cell volume and

Group 8: Malaria positive female children. They consisted of 17 patients and with their packed cell volume, and $\mathrm{Hb}$ values.

\subsubsection{Procedure for Determining Packed Cell Volume Using The Microhematocrit Method.}

Packed cell volume (PCV) is determined by microhematocrit method using a small quality of blood, a capillary tube and a high speed centrifuge.

2.1.2 Principle: The principle in this experiment is the ability of the red blood cells to settle down after centrifuging. This is because they are heavier (sp.gr. about 1090) than plasma (sp.gr. about 1030). The volume occupied by the red blood cells is measured and its ratio with the volume of the whole blood is calculated.

\subsubsection{Method}

The arm of each patient was tied around the upper arm above the cubital fossa with the arm cuff. The medial side cleaned with methylated spirit soaked in cotton wool. The median cubital vein was located and with a needle, the blood collected. The blood was put in a heparinized capillary tube and a spirit lamp was used to seal the end of the capillary tube. The capillary tube was then put into a centrifuge and centrifuged at a speed of $12,000 \mathrm{RV} / \mathrm{min}$ for $5 \mathrm{mins}$. After that, it was taken out and put on the microhematocrit reader allowing the plasma top level to correspond with that of the $100 \%$ mark and the bottom of the tube with that of the $0 \%$ mark. The reading of the RBC level from the hematocrit reader is taken and recorded. The packed cell volume (PCV) value was also recorded.

\subsubsection{Procedure for Hemoglobin Determination}

Methods for hemoglobin determinations are many and varied. The most widely used automated method is the cyanmethomoglobin method. To perform this method, blood was mixed with Drabkins solution, a solution that contains ferricyanide and cyanide. The ferricyanide oxidizes the iron in the hemoglobin, thereby changing hemoglobin to methemoglobin. Methemoglobin then unites with the cyanide to form cyanmethemoglobin. Cyanmethemoglobin produces a color which is measured in a calorimeter, spectrophotometer, or automated instrument. The color relates to the concentration of hemoglobin in blood. 
Manual method for hemoglobin determination is the Haden-Hausse and Sahli-Hellige methods. In these methods, blood was mixed with HCL. This hemolyzes the red cells and releases hemoglobin which in turn is converted to a brownish-colored solution of acid hematin which was then prepared with a color standard.

\subsubsection{Statistical Analysis}

Data were expressed as mean, SD. Student's t-test was therefore used in carrying out statistical analysis. The unpaired t-test was used to compare and test the levels of significance of two data by comparing them. $\mathrm{P}$ value $\leq$ 0.05 was taken as a significant difference.

\section{RESULTS}

Table 1: showing pcv and hb values with the mean and standard error of mean Values of male and female adults.

\begin{tabular}{|l|l|l|l|l|}
\hline & \multicolumn{2}{|c|}{ ADULT MALES } & \multicolumn{2}{l|}{ ADULT FEMALES } \\
\hline GROUPS & PCV & Hb & PCV & Hb \\
\hline CONTROL & $32.94 \pm 3.59$ & $10.97 \pm 1.19$ & $34.13 \pm 0.99$ & $11.37 \pm 0.33$ \\
& & & & \\
\hline POSITIVE & $44.09 \pm 1.58$ & $14.69 \pm 0.53$ & $18.41 \pm 3.55$ & $12.09 \pm 0.54$ \\
& & & & \\
\hline
\end{tabular}

Table 2: showing pcv and hb values with the mean and standard error of mean Values of male and female children.

\begin{tabular}{|c|l|l|l|l|}
\hline & \multicolumn{2}{|l|}{ MALE CHILDREN } & \multicolumn{2}{l|}{ FEMALE CHILDREN } \\
\hline GROUPS & PCV & Hb & PCV & Hb \\
\hline CONTROL & $22.75 \pm 3.89$ & $7.58 \pm 1.30$ & $32.94 \pm 3.59$ & $10.97 \pm 1.19$ \\
& & & & \\
\hline POSITIVE & $18.41 \pm 3.55$ & $5.92 \pm 1.14$ & $44.09 \pm 1.58$ & $14.69 \pm 0.53$ \\
& & & & \\
\hline
\end{tabular}

Table 3: showing comparism between group 1 and group 2, group 3 and 4.

\begin{tabular}{|c|c|c|c|c|}
\hline GROUPS & MEAN & $\begin{array}{l}\text { STANDARD } \\
\text { DEVIATION }\end{array}$ & $\begin{array}{l}\text { STANDARD } \\
\text { ERROR OF } \\
\text { MEAN }\end{array}$ & SIG (2-tailed) \\
\hline $\begin{array}{lr}\text { GROUP } & \mathbf{1} \\
\text { (CONTROL } & \text { FOR } \\
\text { MALE } & \text { ADULTS } \\
\text { )AND } & \\
\text { GROUP2(MALARIA } \\
\text { POSITIVE } & \text { MALE } \\
\text { ADULTS) } & \end{array}$ & -11.16 & 21.23 & 3.75 & $.006 *$ \\
\hline $\begin{array}{lr}\text { GROUP } & \mathbf{3} \\
\text { (CONTROL } & \text { FOR } \\
\text { FEMALE } & \text { ADULTS) } \\
\text { AND } & \\
\text { GROUP4(MALARIA } \\
\text { POSITIVE } & \text { FEMALE } \\
\text { ADULTS) } & \end{array}$ & 15.72 & 21.05 & 3.72 & $.000 *$ \\
\hline
\end{tabular}

KEY: $\quad * \mathrm{P}<0.05$,

A statistically significant difference was seen between the groups.

$$
* * \mathrm{P}<0.01
$$


Evaluation of pcv and hemoglobin variations among malaria positive...

Table 4: showing comparism between group 5 and 6, group 7 and 8.

\begin{tabular}{|l|l|l|l|l|}
\hline GROUPS & MEAN & $\begin{array}{l}\text { STANDARD } \\
\text { DEVIATION }\end{array}$ & $\begin{array}{l}\text { STANDARD } \\
\text { ERROR OF } \\
\text { MEAN }\end{array}$ & SIG (2-tailed) \\
\hline GROUP 5 (CONTROL & 4.34 & 10.81 & 1.91 & $.030 *$ \\
FOR MALE & & & \\
CHILDREN) AND \\
GROUP 6 (MALARIA \\
$\begin{array}{l}\text { POSITIVE MALE } \\
\text { CHILDREN) }\end{array}$ & & & \\
\hline GROUP 7 (CONTROL & & & & \\
FOR FERALE & & 17.54 & 3.10 & $.008 *$ \\
CHILDREN) AND & & & & \\
GROUP 8 (MALARIA & & & & \\
POSITIVE FEMALE & & & & \\
CHILDREN) & & & \\
\hline
\end{tabular}

KEY:

A statistically significant significance was seen between the groups.

$* \mathrm{P}<0.05$

$* * \mathrm{P}<0.01$

\section{DISCUSSION}

The results in the study showed that there was a significant difference between the packed cell volume values of control male adults in group 1 and male positive children in group 2. This was because malaria parasite caused excessive destruction and reduced production of red cells. The hemoglobin values of these two groups when compared had $\mathrm{P}$ values less than 0.05 thus it was statistically significant. Control female adults group 3 and positive female children group 4 had two-tailed $P$ value less than 0.05 and by conventional criteria, this difference was considered to be statistically significant. They also have hemoglobin values when compared showed $\mathrm{P}$ values greater than 0.05 thus are considered insignificant. Packed cell volume values of control male children in group 5 and positive male children in group 6 had two-tailed $\mathrm{P}$ values less than 0.05 . By conventional criteria, this difference is considered to be very statistically significant. They also had hemoglobin values which showed $\mathrm{P}$ values less than 0.05 thus was statistically significant. Packed cell volume values of control female children in group 7 and the positive female children group 8 had two-tailed $\mathrm{P}$ value less than 0.05 and by conventional criteria, this difference is considered to be statistically significant. They also had hemoglobin values with $\mathrm{P}$ values greater than 0.05 thus was statistically significant. The significant difference seen between the packed cell volume values of the control groups and the positive groups is due to the increase in destruction of red blood cells and reduced production. The red cells are destroyed during the parasites growth cycle. Great work has been done to combat this in Nigeria. Chloroquine, drug was formally used to treat malaria but has been reported to produce chloroquine-resistance thus combination therapy is used now for malaria.

\section{CONCLUSION}

From this research work done above, $\mathrm{P}$ values of packed cell volume and hemoglobin values for malaria and non malaria patients studied from the ECWA Community Health Centre Bukuru in Jos was statistically significant thus a difference was established between malaria positive patients and non malaria patients which were used as the control groups. Thus it proves other studies that have been done which showed a decrease in Packed Cell Volume values of malaria positive subjects due to the excessive destruction of the red blood cells. 


\section{REFERENCES}

[1]. Brown A, Barbara, (1988): Hematology-Principles and Procedures, 5th edition, p. 83.

[2]. Calis JC, Phiri KS, Faragher EB, Brabin BJ, Bates I, Cuevas LE, de Haan RJ, Phiri AI, Malange P, Khoka M: (2008). Severe anemia in Malawian children, The New England Journal of Medicine (358): 888-899.

[3]. Cox-Singh, Davis TM, Lee KS (2008). Plasmodium knowlesi malaria in humans is widely distributed and potentially life threatening. Clinical Infectious Disease; (46):165

[4]. Dondorp AM, Kager PA, Vreeken J, White NJ (2000), Abnormal blood flow and red blood cell deformability in severe malaria. Parasitol Today; (16): 228-232.

[5]. Weatherall DJ \& Abdalla S (1982), The Anaemia Of Plasmodium Falciparum Malaria, British Medical Bulletin, vol, 38, (2) pp 147-151

[6]. Fairhurst RM, Wellems TE (2009) Plasmodium species (Malaria). Principles and Practice of Infectious Diseases. 7th ed: chap 275.

[7]. Oni GA and O.O Oguntibeju (2012) Relationship between malaria parasite density and children anemia. International journal in Pathology.

[8]. Harmening, Denise (1992): Clinical Hematology and Fundamentals of Hemostasis, 3rd edition, pp. $605-606$.

[9]. Jawet, Melnick \& Adelbergs: Medical microbiology (2010) 25 ${ }^{\text {th }}$ Edition, Chaper 46;page 677-680.

[10]. Kagu MB, Kawuwa MB, Gadzama GB (2007) Anaemia in pregnancy: a cross-sectional study of pregnant women in a Sahelian tertiary hospital in Northeastern Nigeria. Journal Obstetrics Gynaecology, (27):676-679..

[11]. Marks PW, Glader B, Hoffman R, Benz EJ, Shattil SS, (2008); Approach to anemia in the adult and child, 5th ed: chap 34.

[12]. Phillips RE, Pasvol G (1992): Anaemia of Plasmodium falciparum malaria. Baillierers Clinical Haematology. (2):315-30.

[13]. Schellenburg, D, Schellenberg, and J.R., and Moshi, A. (2003); The silent burden of anaemia in Tanzanian children: a community - based study, Bull World Health Organ. (18): 581 - 90.

[14]. Takem Ebako, Eric Achidi and Peter Ndumbe (2010); An update of malaria infections and anemia in adults in Beea, Cameroon. License BioMed Central Research Notes: (3) 121

[15]. Weatherall DJ, Miller LH, Baruch DI, Marsh K, Doumbo OK, Casals-Pascual \& Roberts DJ. (2002), Malaria and the Red Cell; Hematology American Society of (1): 35- 57.Zuckerman K, (2007), Approach to the anemias. 23rd ed: chap 162. 